\title{
完整糖蛋白为准模板的有机相中聚糖的硼亲和 可控定向表面印迹
}

郭展辰, 邢荣荣, 贺晖, 刘震*

南京大学化学化工学院, 生命分析化学国家重点实验室, 南京 210023

*联系人, E-mail: zhenliu@nju.edu.cn

2018-10-10 收稿, 2018-11-12 修回, 2018-11-14 接受, 2018-12-24 网络版发表

国家杰出青年科学基金(21425520)资助

摘要糖蛋白具有十分重要的生理功能和临床价值, 对于糖蛋白的特异性识别具有重要的科学意义和应用价 值. 分子印迹技术是制备具有特异性分子识别的功能聚合物的重要方法, 已经用于糖蛋白的识别. 但是, 在有机 相中以蛋白质为模板的印迹方法容易导致模板蛋白质的变性，不易获得良好的分子识别性能，而以糖链为模板的 印迹方法需要比较复杂的糖链制备过程. 本文提出了直接以完整糖蛋白为准模板, 在乙醇相中可控地印迹其糖链, 用于制备能识别糖蛋白的分子印迹聚合物的方法. 本文以碱性磷酸酶为目标蛋白, 以喼亲和磁性纳米颗粒作为基 础材料, 通过硼亲和作用固定目标糖蛋白, 利用原硅酸四乙酯-无水乙醇印迹体系, 根据糖蛋白糖链的结构, 无须 优化, 直接控制印迹时间, 仅印迹糖链部分, 得到磁性分子印迹纳米颗粒. 所得磁性分子印迹纳米颗粒对目标糖 蛋白具有良好的特异性识别能力, 即使在复杂的实际样品中, 也可以保持这种特性. 本方法直接使用完整糖蛋白 作为模板，无须通过酶切等烦琐步骤获得模板，方法效率高。本文方法在一定程度上克服了传统印迹方法中无法 在有机相中印迹完整蛋白的局限, 拓展了分子印迹技术的应用范围, 在亲和分离与疾病诊断等重要领域中具有重 要的应用潜力.

关键词分子印迹，可控印迹，嗍亲和，磁性纳米颗粒，糖蛋白

糖蛋白是蛋白质家族中很重要的一大类，具有 十分重要的生物功能, 包括分子识别, 信号转导, 细 胞黏附和免疫应答等 ${ }^{[1 \sim 6]}$. 许多糖蛋白可用作疾病诊 断和靶向治疗的重要生物标志物 ${ }^{[7,8]}$. 然而, 很多具 有重要生理意义和临床价值的糖蛋白在体内含量极 低，而与其共存的其他物质通常具有更高的丰度，导 致很多生物样品中的糖蛋白的检测仍旧是具有挑战 性的任务. 因此, 对于糖蛋白的特异性识别和富集具 有重要意义. 尽管抗体已广泛用于特异性识别糖蛋 白 $^{[9]}$, 但其仍具有一些明显的缺点 ${ }^{[10,11]}$, 包括难以制 备、稳定性差、成本高和释放条件苛刻等. 所以, 能
克服抗体的这些缺点的替代方案具有重要的价值和 意义.

分子印迹聚合物(molecularly imprinted polymers, MIPs $)^{[12 ~ 17]}$ 是指在模板分子的存在下通过聚合反应 得到的高分子聚合物, 在移除模板后, 聚合物上留下 与模板分子三维形状及作用位点相互补的分子印迹 空腔, 从而能与模板分子重新结合, 而与其他分子不 结合. 分子印迹聚合物具有专一性好、预见性高、实 用性强等优点, 目前已经成功应用于分离 ${ }^{[18,19]}$ 、传 感 ${ }^{[20,21]}$ 、成像分析 ${ }^{[22 ~ 24]}$ 、单细胞分析 ${ }^{[25]}$ 和靶向治 疗 ${ }^{[26,27]}$ 等领域. 近年来, 研究人员已经发展出一系列

引用格式: 郭展辰, 邢荣荣, 贺晖, 等. 完整糖蛋白为准模板的有机相中聚糖的嗍亲和可控定向表面印迹. 科学通报, 2019,64: 1418-1426 Guo Z C, Xing R R, He H, et al. Boronate affinity controllable oriented surface imprinting of glycans in organic phase using intact glycoproteins as semi-templates (in Chinese). Chin Sci Bull, 2019, 64: 1418-1426, doi: 10.1360/N972018-01006 


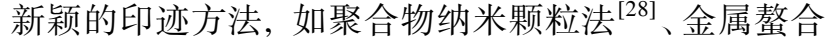
法 ${ }^{[29]}$ 和表面接枝法 ${ }^{[30]}$ 等, 用于制备能特异性识别糖 蛋白的分子印迹聚合物. 然而, 这些方法都有一些共 同的缺点，如通用性差、耗时较长等.

嗍酸可以共价结合含有顺式二羟基的化合物, 如糖蛋白和糖肽等. 在较高的 $\mathrm{pH}$ 条件下, 硼酸可以 和顺式二羟基分子中的邻二羟基发生共价反应, 生 成五元或六元的环状酯; 当环境 $\mathrm{pH}$ 为酸性时, 环状 酯解离, 释放出顺式二羟基分子 ${ }^{[31]}$. 由于顺式二羟 基结构普遍存在于糖蛋白上的糖链中, 所以可以利 用嗍亲和技术达到高效快速富集糖蛋白的目的. 近 年来, 本课题组基于多年来在硼亲和领域的研究积 累 ${ }^{[32,33]}$, 发展了一系列硼亲和分子印迹聚合物材

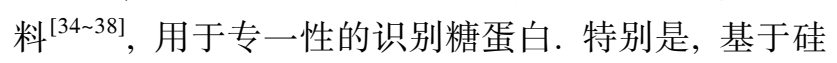
烷化水解的硼亲和可控定向表面印迹方法 ${ }^{[37,38]}$, 适 用性强, 所得分子识别性能优异, 印迹过程简单可 控, 甚至可以对糖肽模板上的糖链实现精准印迹, 得 到只识别糖链的分子印迹材料 ${ }^{[39]}$. 但是, 该印迹方 法所需的印迹模板需要通过酶切等较烦琐步骤制备. 若能直接以完整糖蛋白为印迹模板, 而印迹时仅印 迹糖链部分, 则可以显著提高该方法的整体印迹效 率. 然而, 精准可控印迹的理想条件是在醇相中进行 硅烷化水解, 因为硅烷化试剂在水相中水解速度非 常快且无法控制. 蛋白质大部分都是水溶性的, 其在 有机相中容易发生变性. 因此, 传统的印迹方法中, 通常需要避免在有机相中印迹完整蛋白, 这对蛋白 质的分子印迹产生了一定的限制. 但是基于我们此 前的实验技术, 可以依据糖蛋白特征糖链的长度, 选 择合适的印迹时间, 直接得到所需的印迹层厚度, 仅 印迹糖蛋白上的特征糖链, 这样就可以得到相应的 分子印迹聚合物, 不必担心蛋白质部分的结构变化, 从而克服有机相中无法印迹完整蛋白的局限. 本文以碱性磷酸酶(alkaline phosphatase, ALP)为 目标蛋白, 以嗍亲和磁性纳米颗粒(boronate affinity MNPs, BA-MNPs)为基底材料, 验证了以上设想的可 能性. 碱性磷酸酶是一种重要的糖蛋白酶, 已被用作 临床诊断中多种疾病的标志物 ${ }^{[40]}$. 印迹步骤如图1所 示, 先将目标糖蛋白直接作为印迹模板通过硼亲和 作用固定到嗍亲和磁性纳米颗粒上, 然后加人到原 硅酸四乙酯(TEOS)-无水乙醇印迹体系中, 进行可控 定向表面印迹，控制印迹时间，仅对糖链部分进行印 迹, 除去模板后即得到印迹了糖链的分子印迹磁性 纳米颗粒(molecularly imprinted magnetic nanoparticles, MI-MNPs), 该材料能专一结合目标糖蛋白. 该 方法直接使用完整糖蛋白作为模板, 省去了以前方 法中较复杂的糖肽模板制备步骤，从而显著提高了 方法的效率.

\section{1 材料与方法}

( i ) 材料与仪器. 碱性磷酸酶(ALP)、卵清白蛋 白(ovalbumin, OVA)、牛血清蛋白(bovine serum albumin, BSA)、 $\beta$-酪蛋白 $(\beta$-casein)、辣根过氧化物酶 (horseradish peroxidase, HRP)、腺苷、脱氧腺苷、 $\alpha$ 氧基-4-差基肉桂酸(CHCA)、芥子酸(SA)和原硅酸四 乙酯(TEOS)购于西格玛公司. 2,4-二氟-3-氧基苯嗍酸 (DFFPBA)、三氯化铁六水合物、1,6-已二胺、无水醋 酸钠、乙二醇、硝酸银、柠檬酸三钠、碳酸氢铵、氯 化钠、醋酸、三氟乙酸 $(\mathrm{TFA})$ 、盐酸 $(\mathrm{HCl})$ 、氨水 $(28 \%)$ 、 无水甲醇和无水乙醇购于南京试剂公司. 骨肉瘤癌 症病人血清来源于江苏省南京市鼓楼医院. 透射电 子显微镜(TEM) 实验在一台JEOL-2100F系统(JEOL) 上操作完成. 红外光谱(FT-IR) 分析在Nicolet 6700 FT-IR光谱仪(Thermo Fisher)上完成. 紫外(UV)光谱 分析在NanoDrop 2000/2000C光谱仪(Thermo Fisher)

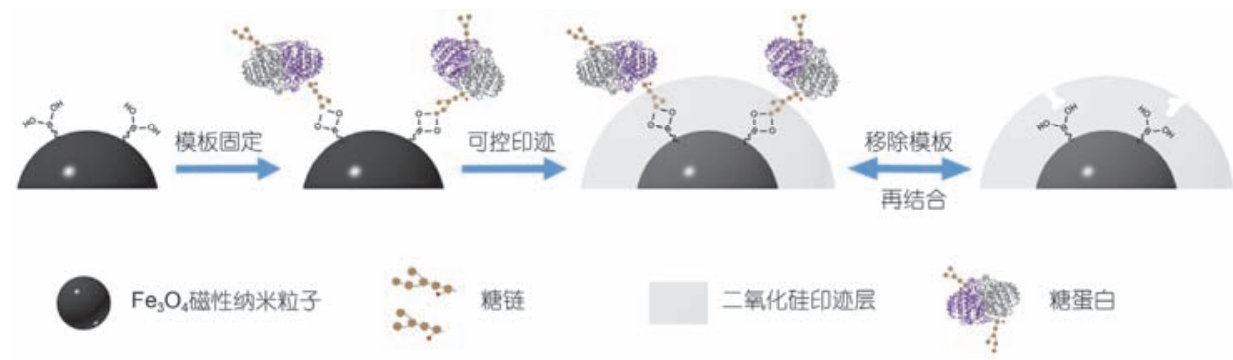

图 1 (网络版彩色)分子印迹磁性纳米颗粒的制备原理图

Figure 1 (Color online) Schematic diagram of molecularly imprinted magnetic nanoparticles 
上完成. 实验中所有的MALDI-TOF MS实验在一台 4800 plus 基质辅助激光解析电离-飞行时间质谱 (MALDI-TOF MS)仪(Appilied Biosystem)上实现.

(ii) MALDI-TOF MS质谱条件的选择. 选用 $355 \mathrm{~nm}$ 的脉冲激光, 激光能量调节到稍微高于國值 以得到好的分辨率和信噪比 $(\mathrm{S} / \mathrm{N})$, 所有的质谱图都 是在正离子模式下采集的, 并选用线性模式来检测 蛋白, 加速电压设定为 $20 \mathrm{kV}$. 整个实验过程在 4000 Series Explorer Software V3.7.0软件上操作完成, 采 集到的数据由Data Explorer Software Version 4.5软件 (Applied Biosystems)处理. 基于以上条件, 选择ALP 作为被分析物, 考察了 $\mathrm{CHCA}$ 和SA两种不同基质, 浓 度分别为 15 和 $10 \mathrm{mg} / \mathrm{mL}$. 具体实验步骤为, 将ALP 蛋白储备液进行梯度稀释(10,100,1000倍), 等量的 基质和样品 $(1 \mu \mathrm{L})$ 依次滴于MALDI靶板上, 室温下 结晶后进行MALDI-TOF MS分析. 由于ALP蛋白分 子量为 $56000 \mathrm{Da}$, 质谱分析质量范围选择 20000 $\sim 100000 \mathrm{Da}$, 聚焦质量56000 Da. 基于质谱离子化效 率, 最终选择 $\mathrm{SA}$ 作为本次实验MALDI-TOF MS分析 的基质.

(iii) BA-MNPs的制备. 首先, 将 $2.0 \mathrm{~g}$ 三氯化铁

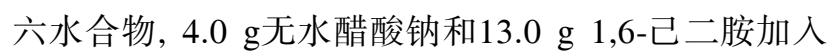
到60 mL乙二醇中, 搅拌均匀, 然后倒人聚四氟乙烯 反应釜中, 在 $198^{\circ} \mathrm{C}$ 温度下反应 $6 \mathrm{~h}$. 得到的产物分别 用水和乙醇各清洗 3 次, 并于 $50^{\circ} \mathrm{C}$ 下真空干燥过夜, 得到氨基修饰磁性纳米粒子 (amino-modified magnetic nanoparticles, AMNPs) ${ }^{[41]}$. 取 $200 \mathrm{mg}$ AMNPs, 加人到 $40 \mathrm{~mL}$ 无水甲醇中, 超声分散, 然后加人 400 $\mathrm{mg}$ DFFPBA和 $1 \%(\mathrm{w} / \mathrm{w})$ 氰基硼氢化钠, 室温下机械 搅拌 $(400 \mathrm{r} / \mathrm{min}) 24 \mathrm{~h}$. 用磁铁收集得到的产物, 然后 分别用水和乙醇各清洗 3 次, 最后在 $50^{\circ} \mathrm{C}$ 真空条件下 干燥过夜, 则得到制备好的BA-MNPs储存备用.

(iv) MI-MNPs的制备. 配置 $50 \mathrm{mmol} / \mathrm{L}$ 碳酸氢 铵 $/ 500 \mathrm{mmol} / \mathrm{L}$ 氯化钠缓冲溶液, 调 $\mathrm{pH}$ 为 8.5 , 取 $2 \mathrm{~mL}$ 该缓冲溶液, 加人 $20 \mathrm{mg}$ 制备好的BA-MNPs, 超声分 散. 同时取 $1 \mathrm{mg}$ 模板蛋白ALP, 溶于 $1 \mathrm{~mL}$ 上述缓冲溶 液中, 得到ALP蛋白储备液. 然后取 $200 \mu \mathrm{L}$ 的ALP蛋 白储备液, 加人到分散好的BA-MNPs溶液中, 室温 条件下振荡 $2 \mathrm{~h}$, 得到固定了ALP蛋白的BA-MNPs, 用磁铁收集产物, 并用 $50 \mathrm{mmol} / \mathrm{L}$ 碳酸氢铵缓冲溶液 $(\mathrm{pH}$ 8.5)清洗, 得到产物 1 . 将产物 1 分散到 $160 \mathrm{~mL}$ 氨 水的无水乙醇溶液中 (氨水含量 $2.8 \mathrm{~mL}$ ), 然后加人 40
$\mathrm{mL} 10 \mathrm{mmol} / \mathrm{L}$ TEOS的无水乙醇溶液, 在室温条件 下缓慢搅拌50 min, 用磁铁收集产物, 并用乙醇清洗 3 次, 在 $40{ }^{\circ} \mathrm{C}$ 下真空干燥过夜, 得到产物 2 . 为了移除 模板蛋白, 将 $20 \mathrm{mg}$ 产物 2 分散到 $2 \mathrm{~mL} 100 \mathrm{mmol} / \mathrm{L}$ 醋 酸溶液中, 室温下振荡 $20 \mathrm{~min}$, 此过程重复 3 次. 移 除模板后, 用磁铁收集印迹得到的MNPs, 并用乙醇 清洗 3 次, 在 $40^{\circ} \mathrm{C}$ 下真空干燥过夜, 得到最终产物 MI-MNPs. 非印迹MNPs(non-imprinted magnetic nanoparticles, NIPs)的制备方法同上，但过程中不加目 标蛋白ALP, 其余步骤完全相同.

( V ) BA-MNPs的嗍亲和选择性的考察. 配制浓 度为 $1 \mathrm{mg} / \mathrm{mL}$ 腺苷或脱氧腺苷溶液, 溶剂为 $50 \mathrm{mmol} / \mathrm{L}$ 碳酸氢铵 $/ 500 \mathrm{mmol} / \mathrm{L}$ 氯化钠缓冲溶液 $(\mathrm{pH} 8.5$ ), 取 $200 \mu \mathrm{L}$ 配置好的溶液, 将 $2 \mathrm{mg}$ BA-MNPs分散其中, 然后在室温条件下, 将混合物在振荡器上振荡 $2 \mathrm{~h}$, 用磁铁将MNPs吸附在离心管管壁上, 分别用 $200 \mu \mathrm{L}$ $50 \mathrm{mmol} / \mathrm{L}$ 碳酸氢铵 $/ 500 \mathrm{mmol} / \mathrm{L}$ 氯化钠缓冲溶液 $(\mathrm{pH}$ $8.5)$ 和 $50 \mathrm{mmol} / \mathrm{L}$ 碳酸氢铵缓冲溶液 $(\mathrm{pH} 8.5)$ 冲洗3次, 再重新将MNPs分散到 $20 \mu \mathrm{L} 100 \mathrm{mmol} / \mathrm{L}$ 醋酸溶液中, 在室温下振荡 $1 \mathrm{~h}$, 最后, 用磁铁将MNPs吸附在离心 管管壁上, 收集解析液. 通过紫外(UV)检测测量解 析液中被MNPs吸附的腺苷或脱氧腺苷的量, 设定 $\mathrm{UV}$ 检测波长为 $260 \mathrm{~nm}$, 重复检测 3 次. 对于 5 种蛋白 质ALP, OVA, BSA, $\beta$-casein和HRP, 配置的蛋白质溶 液浓度为 $0.5 \mathrm{mg} / \mathrm{mL}, \mathrm{UV}$ 检测波长为 $214 \mathrm{~nm}$, 其余步 骤同上. 对于对照试验, 所有实验步骤同上, 在萃取 溶液中不加人蛋白质.

(vi) MI-MNPs的选择性考察. 首先, 将ALP, OVA, BSA, $\beta$-casein和HRP五种蛋白质分别配置成浓 度为 $0.5 \mathrm{mg} / \mathrm{mL}$ 的 $50 \mathrm{mmol} / \mathrm{L}$ 碳酸氢铵 $/ 500 \mathrm{mmol} / \mathrm{L}$ 氯 化钠溶液 $(\mathrm{pH} 8.5$ ), 然后分别取 $2 \mathrm{mg}$ 的MI-MNPs, 分 散到 $200 \mu \mathrm{L}$ 蛋白质溶液中, 在室温条件下振荡 $2 \mathrm{~h}$, 用磁铁将溶液中的产物吸附到离心管管壁上, 分别 用 $200 \mu \mathrm{L} 50 \mathrm{mmol} / \mathrm{L}$ 碳酸氢铵 $/ 500 \mathrm{mmol} / \mathrm{L}$ 氯化钠缓 冲溶液 $(\mathrm{pH} 8.5$ ) 和 $50 \mathrm{mmol} / \mathrm{L}$ 碳酸氢铵缓冲溶液 $(\mathrm{pH}$ 8.5) 冲洗3次, 清洗过后, 重新将 MNPs分散到 $20 \mu \mathrm{L}$ $100 \mathrm{mmol} / \mathrm{L}$ 醋酸溶液中, 室温下在振荡器上振荡 $1 \mathrm{~h}$, 最后，用磁铁将MNPs重新吸附在离心管管壁上，并 用移液枪将离心管里的解析液转移出来. 解析组分 分别进行紫外吸收测量(设定检测波长为 $214 \mathrm{~nm}$ ), 并 进行MALDI-TOF MS分析, 所有测量重复3次. 在对 照试验中, 所有的实验步骤都与上述步骤一样, 但在 
萃取溶液中不加人蛋白质.

(vii) 印迹效率考察. 取 $2 \mathrm{mg}$ 的 BA-MNPs 和 MI-MNPs分别加人到 $200 \mu \mathrm{L} 0.5 \mathrm{mg} / \mathrm{mL}$ 的ALP蛋白质 溶液中, 溶剂为 $50 \mathrm{mmol} / \mathrm{L}$ 碳酸氢铵 $/ 500 \mathrm{mmol} / \mathrm{L}$ 氯化 钠缓冲溶液 $(\mathrm{pH} 8.5)$. 室温下振荡 $2 \mathrm{~h}$, 用磁铁收集溶 液中的MNPs, 分别用 $200 \mu \mathrm{L} 50 \mathrm{mmol} / \mathrm{L}$ 碳酸氢铵/ $500 \mathrm{mmol} / \mathrm{L}$ 氯化钠缓冲溶液 $(\mathrm{pH} 8.5$ ) 和 $50 \mathrm{mmol} / \mathrm{L}$ 碳 酸氢铵缓冲溶液 $(\mathrm{pH}$ 8.5) 冲洗3次, 清洗过后, 重新将 MNPs分散到 $20 \mu \mathrm{L} 100 \mathrm{mmol} / \mathrm{L}$ 醋酸溶液中, 室温下 在振荡器上振荡 $1 \mathrm{~h}$, 最后, 用磁铁将MNPs重新吸附 在离心管管壁上, 并用移液枪将离心管里的解析液 转移出来. 解析组分分别进行紫外吸收测量, 检测波 长为 $214 \mathrm{~nm}$. 由得到的紫外吸收强度估算BA-MNPs 和MI-MNPs所吸附到的ALP的量. 将MI-MNPs吸附 的ALP的量除以BA-MNPs吸附的量, 得到印迹效率. 实验重复3次.

（Viii）选择性萃取癌症病人血清中的ALP. 首 先, 将骨肉瘤癌症病人的血清样品用 $50 \mathrm{mmol} / \mathrm{L}$ 碳酸 氢铵 $/ 500 \mathrm{mmol} / \mathrm{L}$ 氯化钠缓冲溶液 $(\mathrm{pH} 8.5$ ) 稀释 10 倍, 得到样品溶液, 用MALDI-TOF MS进行检测. 称取 $2 \mathrm{mg}$ MI-MNPs, 分别加人到 $200 \mu \mathrm{L}$ 上述样品溶液中, 并在室温下振荡 $2 \mathrm{~h}$, 用磁铁将溶液中的MNPs吸附到 离心管管壁上，用 $200 \mu \mathrm{L} 50 \mathrm{mmol} / \mathrm{L}$ 碳酸氢铵 $/ 500$ $\mathrm{mmol} / \mathrm{L}$ 氯化钠缓冲溶液 $(\mathrm{pH} 8.5)$ 和 $50 \mathrm{mmol} / \mathrm{L}$ 碳酸氢 铵缓冲溶液 ( $\mathrm{pH}$ 8.5) 分别冲洗3次, 清洗过后, 重新将 MNPs分散到 $20 \mu \mathrm{L} 100 \mathrm{mmol} / \mathrm{L}$ 醋酸溶液中, 在振荡 器上室温振荡 $1 \mathrm{~h}$, 最后, 用磁铁将MNPs重新吸附在 离心管管壁上, 并用移液枪将离心管里的解析液转 移出来, 得到的解析液直接用MALDI-TOF MS检测. 我们还考察了NIPs的性能，所有步骤同上.

\section{2 结果与讨论}

\subsection{MNPs的表征}

实验合成得到的MNPs通过TEM进行表征, 如图 2(a) (c) 所示, BA-MNPs, MI-MNPs和NIPs成圆球状, 尺寸均一, 直径约为 $100 \mathrm{~nm}$. 由于磁核外印迹层厚度 较薄 (约为几个纳米), 通过 TEM无法观察印迹前 BA-MNPs和印迹后MI-MNPs的尺寸差别.

MI-MNPs 在水溶液中分散性良好，且通过磁铁 吸附, 分散的材料能被迅速的吸附在容器壁上, 如图 2(d)所示, 在移去磁铁后, 吸附在壁上的MNPs通过

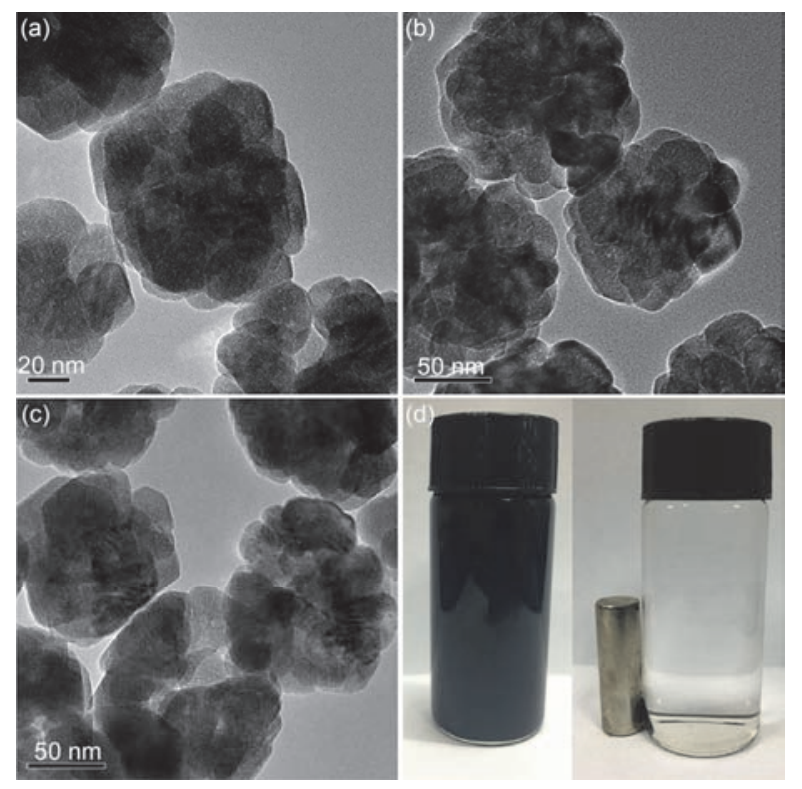

图 2 TEM表征. (a) BA-MNPs; (b) MI-MNPs; (c) NIPs. (d) MI-MNPs 的分散和磁分离照片

Figure 2 TEM images of BA-MNPs (a), MI-MNPs (b), NIPs (c). (d) Photographs showing dispersion and magnetic separation of the MIMNPs

简单的超声可以重新分散到溶液中.

\section{2 印迹时间的选择}

本文选取的目标糖蛋白为 ALP, 以其糖链为实 际印迹模板. ALP是一个带有 2 个糖基化位点的糖蛋 白，但是它的糖基化位点上可以连接至少 17 种不同 结构的糖链, 其中有两种糖链的含量可以达到 $75 \%{ }^{[42]}$. 其结构如图3所示，其尺寸用ChemBio 3D软 件估算, 得到两种糖链的长度分别为 3.27 (图3左)与 $3.54 \mathrm{~nm}$ (图3右). 在印迹时, 为了保证得到有效的印 迹空腔，同时考虑到蛋白质结构的变异可能会导致 糖链局部被包裹在蛋白质结构内，因此选取印迹层 的厚度一般为糖链长度的 $70 \%$ 80\% . 而根据我们之

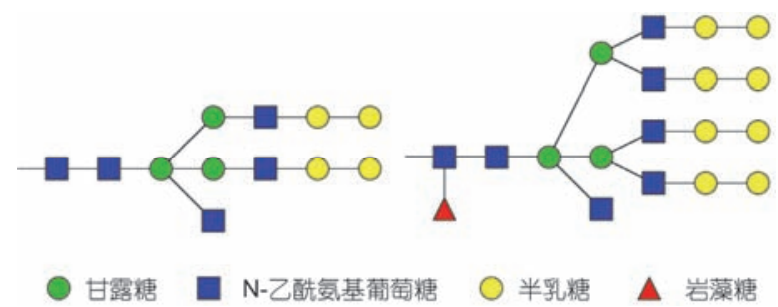

图 3 (网络版彩色)模板糖链的结构

Figure 3 (Color online) The structures of the most abundant glycans of ALP 
前的工作 ${ }^{[37]}$, 印迹层厚度与印迹时间的关系为 $y=$ $0.04 x+0.51\left(R^{2}=0.99\right)$, 其中 $y$ 为印迹层厚度 $(\mathrm{nm}), x$ 为 印迹时间( $\mathrm{min})$. 因此, 我们选择印迹时间为 $50 \mathrm{~min}$, 预估得到印迹层厚度为 $2.51 \mathrm{~nm}$.

\subsection{MNPs选择性和结合性能考察}

( i ) BA-MNPs的硼亲和选择性. 对于BA-MNPs 的嗍亲和选择性的考察, 选择腺苷和脱氧腺苷作为 测试分析物. 腺苷具有顺式二差基结构, 能够通过硼 亲和作用被BA-MNPs抓取; 而脱氧腺苷则没有顺式 二羟基结构, 因此不能被抓取. 实验结果如图4(a)所 示, 从图中可以看出, BA-MNPs对腺苷有明显的抓 取, 而对脱氧腺苷则没有抓取, 证明实验合成的 BA-MNPs有很好的嗍亲和选择性.

选择了 5 种不同的蛋白质考察以上材料的硼亲和 选择性, 包括糖蛋白ALP, OVA和HRP以及非糖蛋白 BSA和 $\beta$-casein. 对于糖蛋白来说, 其结构上含有具 有顺式二差基结构的糖链, 因此可以通过嗍亲和作 用被抓取; 而非糖蛋白上没有顺式二羟基结构的糖 链, 因此不能被抓取. 如图4(b)结果显示, 该嗍亲和 材料对于糖蛋白ALP, OVA和HRP有明显抓取, 而对 非糖蛋白BSA和 $\beta$-casein则几乎不抓取, 说明了所制 备的基础材料有良好的硼亲和选择性.

(ii) MI-MNPs的选择性. MI-MNPs的选择性通 过萃取ALP, OVA, BSA, $\beta$-casein和HRP来验证, 其中 ALP作为目标蛋白, 而OVA, BSA, $\beta$-casein和HRP作 为竞争蛋白. 结果如图5所示, MI-MNPs仅对ALP有 明显的结合, 而对其他 4 种蛋白的结合量都很小, 证 明MI-MNPs对 ALP具有良好的特异性结合能力, 该

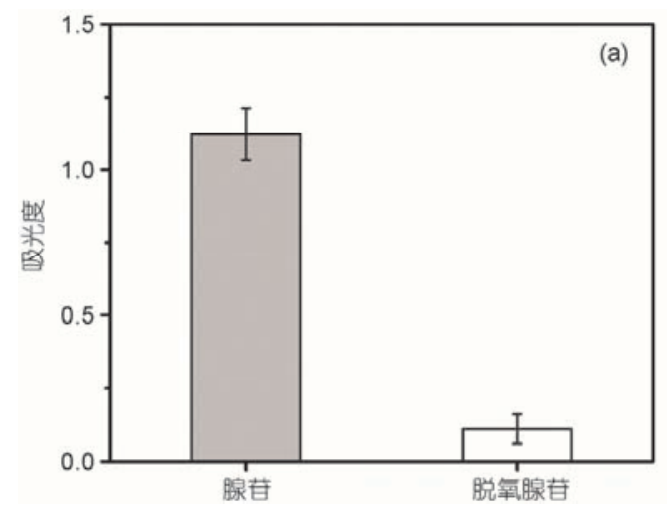

结果被相应的MALDI-TOF MS 分析结果进一步证实 (图 6). 通过对比 MI-MNPs 和 NIPs 对 ALP的结合量, 得到本方法的印迹因子(IF)为 10.1. 印迹效率通过印 迹后MI-MNPs对ALP的结合量与印迹前BA-MNPs对 ALP的结合量之比计算得到, 为 $51.4 \%$, 明显高于之 前的工作 $\left(48.5 \%{ }^{[36]}, 43.5 \%{ }^{[37]}\right.$ 和 $\left.46.2 \%{ }^{[39]}\right)$, 表明本印 迹方法的效率更高.

\subsection{MI-MNPs在实际样品中的应用}

骨肉瘤是一种具有较高恶性程度的骨的原发性 肿瘤, 其患者体内的ALP含量会发生病理性升高. 从 血清样品的检测结果中, 可以发现, 即使在ALP发生 病理性升高的癌症病人血清中, ALP相对含量也十分 低, 从质谱图中基本上看不到(图7(a)). 但是, 经过 MI-MNPs萃取后, 解析液在MALDI-TOF MS下, 信 号十分明显(图7(b)). 这充分说明本文的分子印迹聚 合物对于ALP蛋白的专一性识别和选择性富集能力, 即使在痕量情况下, 效果仍然十分明显. ALP在骨肉 瘤癌症病人血清中的含量水平与骨肉瘤的不同病理 类型有关. 同时，对于治疗前患者体内ALP水平的检 测, 具有一定的治疗预判价值, 有助于对患者治疗方 案进行选择, 提高治疗效果. 因此, 本文合成的MIMNPs对于骨肉瘤癌症病人血清中痕量ALP的成功富 集, 充分展现了本方法制备的分子印迹聚合物在实 际样品尤其是复杂的生物样品中重要的应用价值.

\section{3 结论}

本文提出了在有机相中以目标糖蛋白为准模板, 通过可控定向表面印迹仅印迹其糖链部分的新颖分

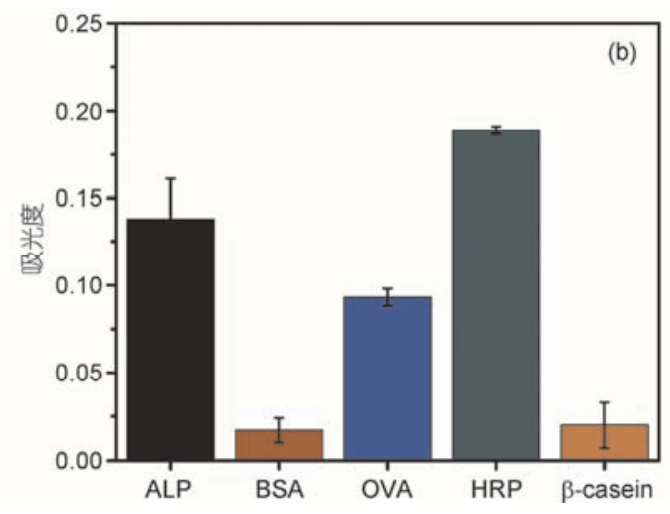

图 4 (网络版彩色)BA-MNPs对腺苷和脱氧腺苷(a)和不同蛋白(b)的抓取结果

Figure 4 (Color online) Comparison of the amount of adenosine and deoxyadenosine (a), different proteins (b) captured by BA-MNPs 


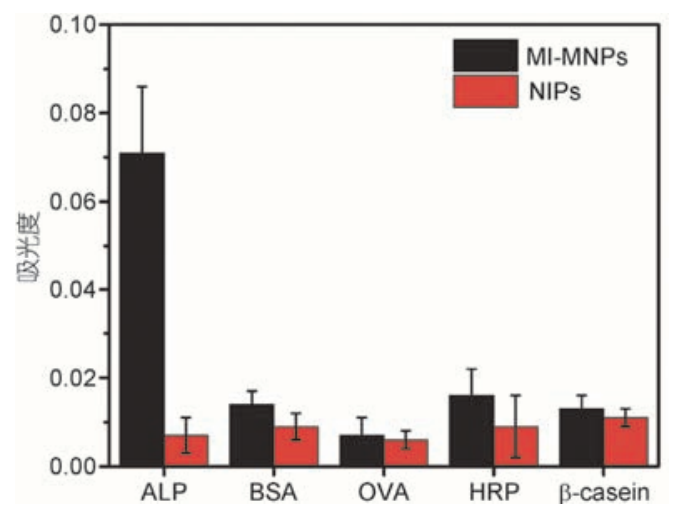

图 5 (网络版彩色)MI-MNPs和NIPs对于不同蛋白的抓取结果

Figure 5 (Color online) Comparison of the amount of different proteins captured by the MI-MNPs and NIPs
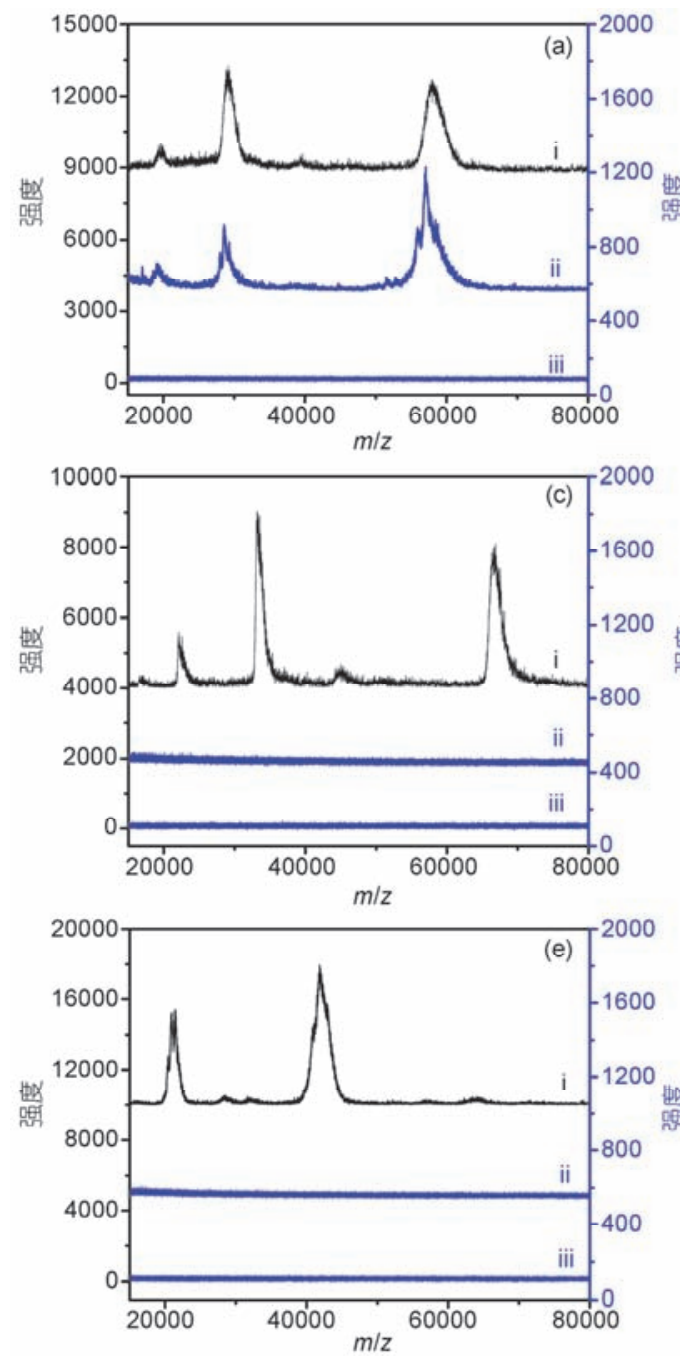

子印迹方法. 以碱性磷酸酶为例, 合成了能专一识别 该糖蛋白的磁性分子印迹纳米材料. 该印迹方法无须 复杂的糖链模板制备步骤，根据特征糖链结构，通过 控制印迹时间，直接印迹完整糖蛋白上的糖链，方法 简便高效. 本方法的印迹过程中，可以忽略有机相对 目标蛋白造成的结构变化. 所得分子印迹材料对于目 标糖蛋白表现出良好的特异性，即使在复杂的实际样 品中，也可以保存这种特性. 本文方法的制备步骤简 单，制备成本低，材料结合目标物后的释放条件也比 较温和. 同时，该方法可以扩展到其他糖蛋白的识别。 因此，本文方法及所合成的分子印迹聚合物在疾病诊 断等许多重要的领域中具有重要的应用潜力.
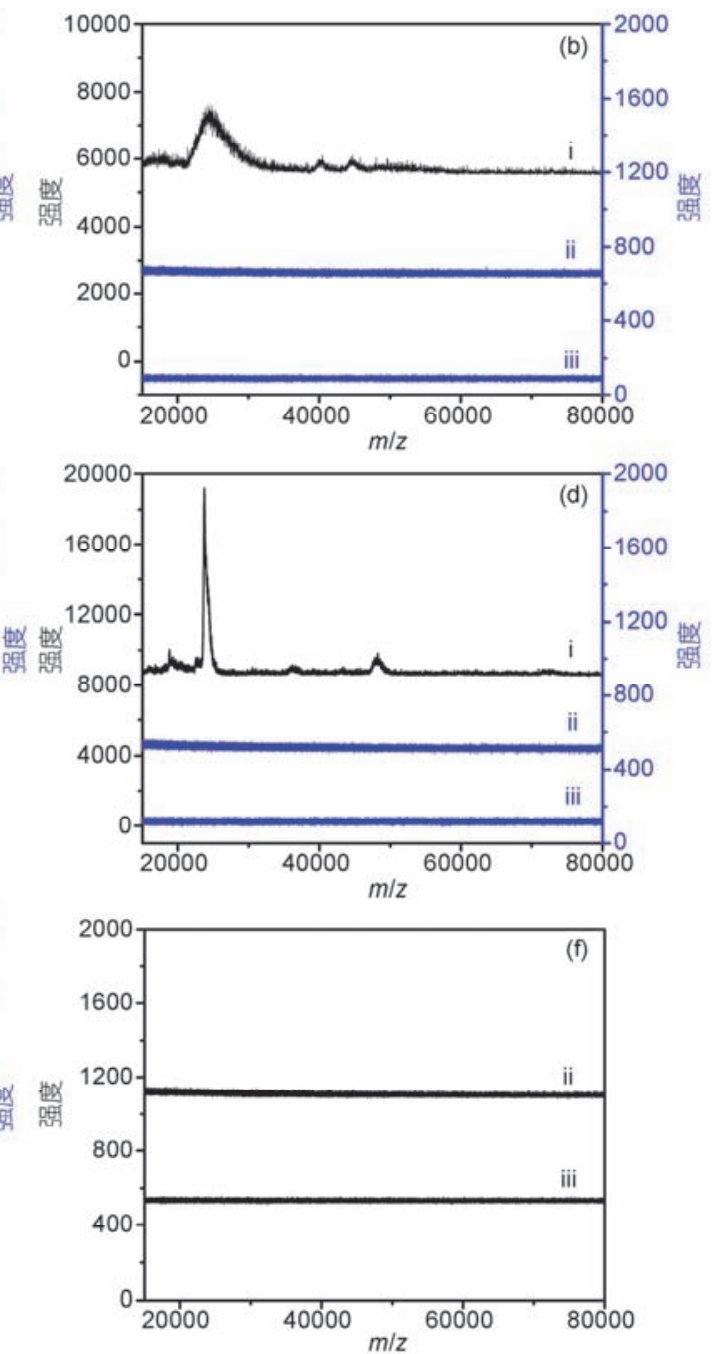

图 6 (网络版彩色)MALDI-TOF MS检测图谱. (a) ALP, (b) OVA, (c) BSA, (d) $\beta$-casein, (e) HRP, (f) 空白. (i) 蛋白质标准品, (ii) MI-MNPs萃取 的蛋白质, (iii) NIPs萃取的蛋白质

Figure 6 (Color online) MALDI-TOF MS spectra of direct analysis of proteins (i), proteins extracted by the MI-MNPs prepared (ii) and by corresponding NIPs from different samples (iii). (a) ALP, (b) OVA, (c) BSA, (d) $\beta$-casein, (e) HRP, (f) blank 


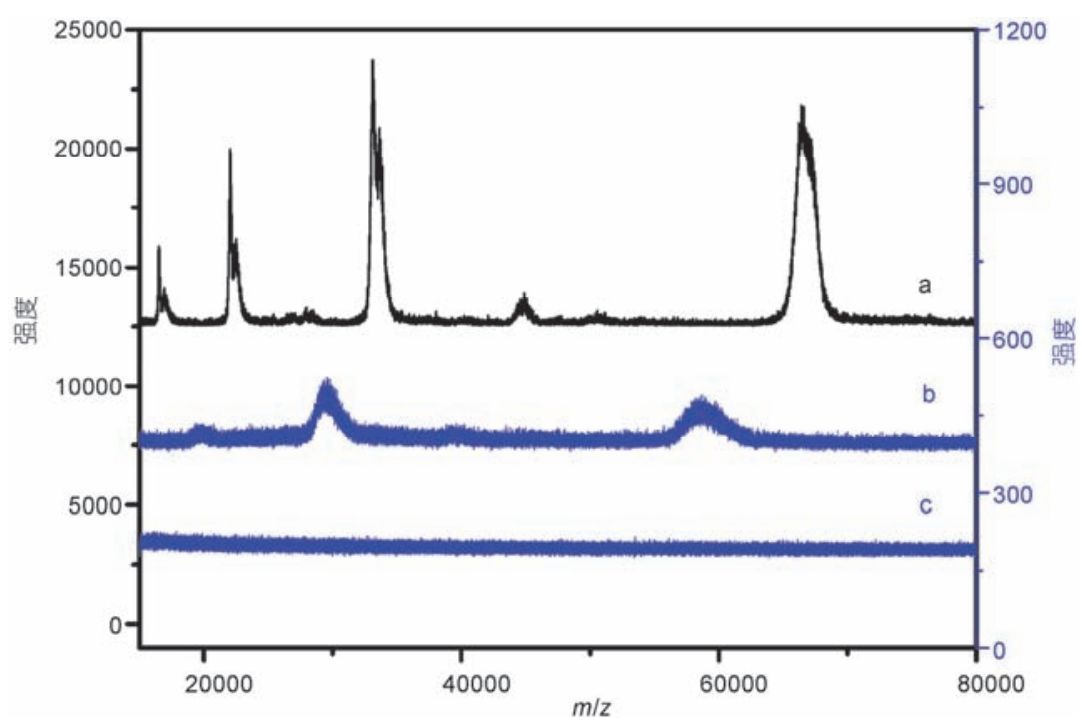

图 7 (网络版彩色)MALDI-TOF MS检测图谱. (a) 血清样品; (b) MI-MNPs萃取后; (c) NIPs萃取后

Figure 7 (Color online) MALDI-TOF MS spectra for the analysis of human serum. (a) Direct analysis; (b) analysis after extracted by the MI-MNPs; (c) analysis after extracted by NIPs

\section{参考文献}

1 Wu L, Qu X G. Cancer biomarker detection: Recent achievements and challenges. Chem Soc Rev, 2015, 44: 2963-2997

2 Dwek R A. Glycobiology: Toward understanding the function of sugars. Chem Rev, 1996, 96: 683-720

3 Ohtsubo K, Marth J D. Glycosylation in cellular mechanisms of health and disease. Cell, 2006, 126: 855-867

4 Chandler K, Goldman R. Glycoprotein disease markers and single protein-omics. Mol Cell Proteomics, 2013, 12: 836-845

5 Rudd P M, Wormald M R, Dwek R A. Glycosylation and the immune system. J Protein Chem, 1998, 17: 519-519

6 Morelle W, Michalski J C. Analysis of protein glycosylation by mass spectrometry. Nat Protoc, 2007, 2: 1585-1602

7 Ludwig J A, Weinstein J N. Biomarkers in cancer staging, prognosis and treatment selection. Nat Rev Cancer, 2005, 5: 845-856

8 Tian Y, Zhang H. Characterization of disease-associated n-linked glycoproteins. Proteomics, 2013, 13: 504-511

9 Bordon Y. Pattern recognition receptors picking lox to find antibodies. Nat Rev Immunol, 2014, 14: 716-716

10 Baker M. Blame it on the antibodies. Nature, 2015, 521: 274-276

11 Baker M. Antibody anarchy: A call to order. Nature, 2015, 527: 545-551

12 Wulff G, Sarhan A. The use of polymers with enzyme-analogous structures for the resolution of racemates. Angew Chem Int Edit, 1972, 11: $341-346$

13 Vlatakis G, Andersson L I, Muller R, et al. Drug assay using antibody mimics made by molecular imprinting. Nature, 1993, 361: 645-647

14 Wulff G. Molecular imprinting in cross-linked materials with the aid of molecular templates-A way towards artificial antibodies. Angew Chem Int Edit, 1995, 34: 1812-1832

15 Shi H Q, Tsai W B, Garrison M D, et al. Template-imprinted nanostructured surfaces for protein recognition. Nature, 1999, 398: 593-597

16 Nishino H, Huang C S, Shea K J. Selective protein capture by epitope imprinting. Angew Chem Int Edit, 2006, 45: 2392-2396

17 Haupt K, Mosbach K. Molecularly imprinted polymers and their use in biomimetic sensors. Chem Rev, 2000, 100: 2495-2504

18 Hart B R, And D J R, Shea K J. Discrimination between enantiomers of structurally related molecules: Separation of benzodiazepines by molecularly imprinted polymers. J Am Chem Soc, 2000, 122: 460-465

19 Nematollahzadeh A, Sun W, Aureliano C S A, et al. High-capacity hierarchically imprinted polymer beads for protein recognition and capture. Angew Chem Int Edit, 2011, 50: 495-498

20 Kugimiya A, Takeuchi T. Surface plasmon resonance sensor using molecularly imprinted polymer for detection of sialic acid. Biosens Bioelectron, 2001, 16: 1059-1062

21 Fuchs Y, Soppera O, Mayes A G, et al. Holographic molecularly imprinted polymers for label-free chemical sensing. Adv Mater, 2013, 25: 566-570 
22 Kunath S, Panagiotopoulou M, Maximilien J, et al. Cell and tissue imaging with molecularly imprinted polymers as plastic antibody mimics. Adv Healthc Mater, 2015, 4: 1322-1326

23 Yin D Y, Wang S S, He Y J, et al. Surface-enhanced Raman scattering imaging of cancer cells and tissues via sialic acid-imprinted nanotags. Chem Commun, 2015, 51: 17696-17699

24 Wang S S, Wen Y R, Wang Y J, et al. Pattern recognition of cells via multiplexed imaging with monosaccharide-imprinted quantum dots. Anal Chem, 2017, 89: 5646-5652

25 Liu J, Yin D Y, Wang S S, et al. Probing low-copy-number proteins in a single living cell. Angew Chem Int Edit, 2016, 55: 13215-13218

26 Sellergren B, Allender C J. Molecularly imprinted polymers: A bridge to advanced drug delivery. Adv Drug Deliver Rev, 2005, 57: $1733-1741$

27 Cecchini A, Raffa V, Canfarotta F, et al. In vivo recognition of human vascular endothelial growth factor by molecularly imprinted polymers. Nano Lett, 2017, 17: 2307-2312

28 Hoshino Y, Koide H, Urakami T, et al. Recognition, neutralization, and clearance of target peptides in the bloodstream of living mice by molecularly imprinted polymer nanoparticles: A plastic antibody. J Am Chem Soc, 2010, 132: 6644-6645

29 Li S W, Yang K G, Deng N, et al. Thermoresponsive epitope surface-imprinted nanoparticles for specific capture and release of target protein from human plasma. ACS Appl Mater Inter, 2016, 8: 5747-5751

30 Bossi A, Piletsky S A, Piletska E V, et al. Surface-grafted molecularly imprinted polymers for protein recognition. Anal Chem, 2001, 73: 5281-5286

31 James T D, Sandanayake K, Shinkai S. Saccharide sensing with molecular receptors based on boronic acid. Angew Chem Int Edit, 1996, 35: 1910-1922

32 Li D J, Chen Y, Liu Z. Boronate affinity materials for separation and molecular recognition: Structure, properties and applications. Chem Soc Rev, 2015, 44: 8097-8123

33 Liu Z, He H. Synthesis and applications of boronate affinity materials: From class selectivity to biomimetic specificity. Accounts Chem Res, 2017, 50: 2185-2193

34 Li L, Lu Y, Bie Z J, et al. Photolithographic boronate affinity molecular imprinting: A general and facile approach for glycoprotein imprinting. Angew Chem Int Edit, 2013, 52: 7451-7454

35 Ye J, Chen Y, Liu Z. A boronate affinity sandwich assay: An appealing alternative to immunoassays for the determination of glycoproteins. Angew Chem Int Edit, 2014, 53: 10386-10389

36 Wang S S, Ye J, Bie Z J, et al. Affinity-tunable specific recognition of glycoproteins via boronate affinity-based controllable oriented surface imprinting. Chem Sci, 2014, 5: 1135-1140

37 Bie Z J, Chen Y, Ye J, et al. Boronate-affinity glycan-oriented surface imprinting: A new strategy to mimic lectins for the recognition of an intact glycoprotein and its characteristic fragments. Angew Chem Int Edit, 2015, 54: 10211-10215

38 Xing R R, Wang S S, Bie Z J, et al. Preparation of molecularly imprinted polymers specific to glycoproteins, glycans and monosaccharides via boronate affinity controllable-oriented surface imprinting. Nat Protoc, 2017, 12: 964-987

39 Bie Z J, Xing R R, He X P, et al. Precision imprinting of glycopeptides for facile preparation of glycan-specific artificial antibodies. Anal Chem, 2018, 90: 9845-9852

40 Forneris F, Mattevi A. Enzymes without borders: Mobilizing substrates, delivering products. Science, 2008, 321: 213-216

41 Wang L Y, Bao J, Wang L, et al. One-pot synthesis and bioapplication of amine-functionalized magnetite nanoparticles and hollow nanospheres. Chem-Eur J, 2006, 12: 6341-6347

42 Bublitz R, Hoppe H, Cumme G A, et al. Structural study on the carbohydrate moiety of calf intestinal alkaline phosphatase. J Mass Spectrom, 2001, 36: 960-972 


\title{
Boronate affinity controllable oriented surface imprinting of glycans in organic phase using intact glycoproteins as semi-templates
}

\author{
Zhanchen Guo, Rongrong Xing, Hui He \& Zhen Liu* \\ State Key Laboratory of Analytical Chemistry for Life Science, School of Chemistry and Chemical Engineering, Nanjing University, Nanjing \\ 210023, China \\ *Corresponding author, E-mail: zhenliu@nju.edu.cn
}

Glycoproteins are a large family of proteins which have great biological and clinical importance including molecular recognition, signal transduction, cell adhesion and immune response. Many glycoproteins are important biomarkers for disease diagnosis and as therapeutic targets. However, glycoproteins are present in very low abundance in the body and coexist alongside interfering species present at much higher abundance. So, specific recognition of glycoproteins is of great significance. Although antibodies are commonly used to solve this issue, they are associated with some apparent drawbacks, such as, difficult to prepare, poor storage stability, high cost and requiring harsh conditions for target release. Therefore, novel alternatives are highly desirable. Molecularly imprinted polymers (MIPs), which are synthesized through polymerization in the presence of a template, exhibit specific binding towards the template molecules. A series of molecular imprinting approaches have been developed to produce glycoprotein-specific MIPs. Boronic acids can covalently bind cis-diol groups of cis-diol-containing compounds like glycoproteins and glycopeptides, to form stable fiveor six-membered cyclic esters at relatively high $\mathrm{pH}$ values. The esters dissociate reversibly when the $\mathrm{pH}$ of the environment is made acidic. In recent years, our group has developed a series of boronate affinity molecular imprinting techniques for specific recognition of glycoproteins, especially boronate affinity controllable-oriented surface imprinting method. Based on silane hydrolysis in alcohol phase, this method permits getting the desired thickness of the imprinting layer according to the size of the template molecules. The method allows for easy and efficient preparation of MIPs specific to glycoproteins, glycans, and monosaccharides, enabling promising applications. Recently, we can even achieve precision imprinting of glycopeptides for the facile preparation of glycan-specific MIPs. However, the molecular imprinting of intact proteins in organic phase often results in the denature of the template proteins while imprinting approaches using glycans as the templates require relatively tedious glycan preparation procedure. Herein, we developed a new approach for imprinting in organic phase using an intact target glycoprotein as a semi-template. This method allowed for the imprinting of only the glycans on the target glycoprotein, without worrying about possible denature of the target protein in organic phase. Alkaline phosphatase (ALP), which is a glycoprotein enzyme that has been routinely used as an indicator for several diseases in clinical tests, was used as the target. ALP-specific molecularly imprinted magnetic nanoparticles (MI-MNPs) were prepared using this method. By using boronic acid-functionalized MNPs as the nanocores, the target molecules were immobilized onto the nanocores via boronate affinity. Then, a thin-layer of silica was controllably formed to cover the templates to an appropriate thickness through polycondensation of tetraethyl orthosilicate (TEOS) in ethanol. After that, the templates are removed facilely by washing with an acidic solution to disrupt the boronate affinity interaction. The prepared MIPs exhibited good specificity towards ALP, and this characteristic was preserved even in a complicated real sample. The developed approach exhibited high imprinting efficiency. It overcame the limitations of previous imprinting approaches. Also, the MI-MIPs synthesized in this work were simple to prepare, stable, cost-efficient and easy to collect. Besides, the target release just needed gentle conditions. It can be a promising means to produce glycoprotein-specific MIPs for important applications such as affinity separation and disease diagnosis.

molecular imprinting, controllable imprinting, boronate affinity, magnetic nanoparticle, glycoprotein

doi: 10.1360/N972018-01006 